\title{
Starvation of Prototheca zopfii
}

\author{
By DAVID LLOYD, N. ANGHARAD MORGAN, LYNDA JOHN \\ AND SUSAN E. VENABLES \\ Department of Microbiology, University College, Newport Road, Cardiff CF2 1TA
}

(Received 14 September 1977)

The colourless alga Prototheca zopfii survived carbon-starvation for at least $110 \mathrm{~d}$. Over a period of $21 \mathrm{~d}$ total numbers of organisms and viable organisms declined by $62 \%$ and $68 \%$ respectively. Both acetate-supported and endogenous respiration rates decreased, and the values for adenylate charge decreased from 0.95 to 0.015 after $5 \mathrm{~d}$ starvation. Complex changes in respiratory enzymes, catalase and acid hydrolases occurred over a $27 \mathrm{~d}$ period; cytochromes $b$ and $c$ were modified to protohaem-like and haem $c$-like compounds, and no haem $a$ derivative could be detected. Ultrastructural changes included indentation of cell walls, shrinkage of the cytoplasmic mass, and disorganization of mitochondrial inner membranes, although recognizable mitochondrial profiles were still present after $43 \mathrm{~d}$.

\section{INTRODUCTION}

Although several detailed studies have been made of the biochemical changes which occur during the ageing of bacterial cultures, few comparable studies have been made of eukaryotic micro-organisms (Trinci \& Thurston, 1976). Cultures of Euglena gracilis, when starved for $13 \mathrm{~d}$ remain $95 \%$ viable, but lose much $(45,30,55$ and $90 \%$ respectively) of their protein, DNA, RNA and paramylon (Blum \& Buetow, 1963). Autophagy has been reported both in this system (Brandes et al., 1964; Bertini, Brandes \& Buetow, 1965) and in nutrient-starved Tetrahymena pyriformis (Elliott \& Bak, 1964; Levy \& Elliott, 1968), but there is no conclusive biochemical evidence that autophagic degradation of functional cellular components can provide carbon and energy sources to enable organisms to prolong their survival. More specific mechanisms are involved in the inactivation and degradation of enzymes during carbon-starvation in T. pyriformis (Levy, Sisskin \& McConkey, 1976), Chlorella fusca (Morris \& Syrett, 1965; John, Thurston \& Syrett, 1970) and Saccharomyces cerevisiae (Katsunuma et al., 1972; Luzikov, Makhlis \& Galkin, 1976). Carbon-starvation of $S$. cerevisiae for $20 \mathrm{~d}$ led to loss of two-thirds of the respiratory activity (Miura \& Yanagita, 1972) and Ball \& Atkinson (1975) showed that after $7 \mathrm{~d}$ starvation the adenylate charge had decreased to 0.03 with $34 \%$ loss of viability.

In the present study we show that the colourless alga Prototheca zopfii can survive starvation for as long as $110 \mathrm{~d}$, although respiration and adenylate charge decrease dramatically over the first $7 \mathrm{~d}$.

\section{METHODS}

Growth of the organism. Cultures of Prototheca zopfii Kruger from the Culture Centre of Algae and Protozoa, 36 Storey's Way, Cambridge (catalogue no. 263-5) were grown with $20 \mathrm{~mm}$-sodium acetate as sole source of carbon and energy as previously described (Callely \& Lloyd, 1964) in volumes of up to 101.

Starvation. Carbon-starvation was achieved by forced aeration of cultures at $30^{\circ} \mathrm{C}$ for up to $40 \mathrm{~d}$ using moist air to minimize evaporation. Absence of contaminating organisms was checked by frequent plating on nutrient agar (every $7 \mathrm{~d}$ ).

Cell numbers. Total cell counts were estimated using a Thoma haemocytometer slide (Hawkesley, Lancing,

Vol. 104, No. 2 was issued 14 February 1978 
Sussex). Numbers of viable cells were determined by the plate count method. Dilutions were made in $0.85 \%$ $(\mathrm{w} / \mathrm{v})$ saline and $1 \mathrm{ml}$ quantities were used on shake plates. The medium used was acetate-containing growth medium solidified with $1.2 \%(\mathrm{w} / \mathrm{v})$ Oxoid agar no. 2 . Plates were incubated at $30^{\circ} \mathrm{C}$ for $4 \mathrm{~d}$ before counting colonies.

Harvesting and preparation of cell-free extracts. Organisms were harvested as described previously (Callely \& Lloyd, 1964) and washed once in $10 \mathrm{vol} .20 \mathrm{~mm}$-potassium phosphate buffer before disintegration in a Hughes (1951) bacterial press at $-25^{\circ} \mathrm{C}$. The crushed cells were resuspended in 3 vol. of this buffer and the suspension was centrifuged at $2000 \mathrm{rev}$. $\mathrm{min}^{-1}(800 \mathrm{~g})$ for $10 \mathrm{~min}$ using the $8 \times 50 \mathrm{ml}$ rotor of an MSE ' 18 ' centrifuge. Unbroken organisms (about $30 \%$ of total numbers) and wall fragments were sedimented, and the supernatant (termed the cell-free extract) was carefully decanted.

Enzyme assays. Details of assays for cytochrome $c$ oxidase [ferrocytochrome $c$ : oxygen oxidoreductase; EC 1.9.3.1], catalase [hydrogen-peroxide:hydrogen-peroxide oxidoreductase; EC 1.11.1.6], and acid phosphatase [orthophosphoric-monoester phosphohydrolase (acid optimum); EC 3.1.3.2] using $p$-nitrophenyl phosphate as substrate, have been presented previously (Edwards \& Lloyd, 1977). NAD(P)Hcytochrome $c$ oxidoreductases [NADPH:ferricytochrome oxidoreductase; EC 1.6.99.1] were assayed as described by Cartledge \& Lloyd (1972); NAD(P)H-ferricyanide oxidoreductases [EC 1 .6.99.1] were measured in 20 mM-potassium phosphate buffer at $420 \mathrm{~nm}$ at pH 7.2 with the electron acceptor concentration at $10 \mathrm{~mm}$. Arylesterase [aryl-ester hydrolase; EC 3.1.1.2] was assayed by the method of Huggins \& Lapides (1947) using $50 \mathrm{~mm}$-acetate buffer, $\mathrm{pH} 4 \cdot 2$ and $20 \mathrm{~mm}-p$-nitrophenyl acetate; the reaction was terminated by adding $0.5 \mathrm{M}-\mathrm{Tris} / \mathrm{HCl}$ buffer $\mathrm{pH} 7.0$ and the reaction product was measured at $420 \mathrm{~nm}$. Deoxyribonuclease [deoxyribonucleate 3'-oligonucleotidohydrolase; EC 3.1.4.5] and ribonuclease [ribonucleate 3'-oligonucleotidehydrolase; EC 3.1.4.23] were assayed as described by Müller, Baudhuin \& de Duve (1966). Acid hydrolases were assayed at $30^{\circ} \mathrm{C}$ using frozen-thawed extracts and in the presence of $0.02 \%(\mathrm{v} / \mathrm{v})$ Triton $\mathrm{X}-100$. All other enzymes were assayed at room temperature $\left(20 \pm 2{ }^{\circ} \mathrm{C}\right)$ using freshly prepared extracts. The cell-free extract was diluted in all assays so that reaction rates were proportional to enzyme concentrations.

Analytical methods. Dry weights of cells were determined by filtration on to tared Whatman GF/A filters and drying to constant weight at $90^{\circ} \mathrm{C}$. Polysaccharides were estimated in the residue obtained by autoclaving $10 \mathrm{mg}$ dried cells for $1 \mathrm{~h}$ at $121{ }^{\circ} \mathrm{C}$ with $5 \mathrm{ml} 20 \%$ (w/v) KOH. Glycogen-like material was extracted from this residue by resuspension in $5 \mathrm{ml} 2 \mathrm{M}-\mathrm{HCl}$. The supernatant containing glycogen was decanted from the pelleted residue (3000 rev. $\mathrm{min}^{-1}, 1006 \mathrm{~g}$ for $10 \mathrm{~min}$ ) and the sediment was washed well in distilled water until neutral. The reducing sugar content of each suspension was estimated by the anthrone method of Chung \& Nickerson (1954). Lipid was extracted from dried cells by separate methanol and ether extractions. Protein was estimated in whole cell suspensions by the biuret method of Stickland (1951) and in extracts by the method of Lowry et al. (1951), both with bovine serum albumin as standard. Oxygen uptake was measured polarographically by the method of Lloyd \& Brookman (1967). Cytochrome spectra at $77 \mathrm{~K}$ were obtained as detailed by Edwards et al. (1977). Measurements of adenine nucleotide levels were as described by Edwards, Statham \& Lloyd (1975) using luciferase assays on extracts from $1 \mathrm{ml}$ of culture prepared by chloroform extraction. ATP, ADP and AMP were estimated by the method of Chapman, Fall \& Atkinson (1971) using ATP as a calibration standard. Adenine nucleotides in the growth medium were estimated by filtering the culture sample (Whatman GF/A filter) and repeating the above procedure on $1 \mathrm{ml}$ of filtrate. Adenylate charge (Atkinson \& Walton, 1967) is defined as:

$$
\text { adenylate charge }=\frac{\mathrm{ATP}+\frac{1}{2} \mathrm{ADP}}{\mathrm{ATP}+\mathrm{ADP}+\mathrm{AMP}}
$$

Quenching of samples for adenine nucleotide assays employed a mixing time of $0.2 \mathrm{~s}$ ('Whirlimixing' with chloroform) after rapid sampling of cell suspensions directly into the tubes.

Electron microscopy. Electron micrographs were obtained as described by Cartledge \& Lloyd (1972).

Chemicals. Cytochrome $c$ (type III, horse heart), NADH (type III, yeast), NADPH (type I), buffered firefly lantern extracts, myokinase (grade III, rabbit muscle), pyruvate kinase (type II, rabbit skeletal muscle), phosphoenolpyruvic acid (sodium salt), ATP (disodium salt), $p$-nitrophenyl derivatives and Triton X-100 were from Sigma. Bovine serum albumin was from Armour Pharmaceuticals, Eastbourne, Sussex.

\section{RESULTS}

\section{Changes in viability and gross composition}

The organisms grew with a mean generation time (mid-exponential phase of growth) of $7 \mathrm{~h}$ and attained a stationary phase population of $6.6 \times 10^{5}$ organisms $\mathrm{ml}^{-1}$ after $30 \mathrm{~h}$. Over a period of $24 \mathrm{~d}$ the absorbance of a carbon-starved culture at $400 \mathrm{~nm}$ decreased by $36 \%$ and the dry weight decreased by $35 \%$ (Fig. 1a). The total numbers and viable numbers of 


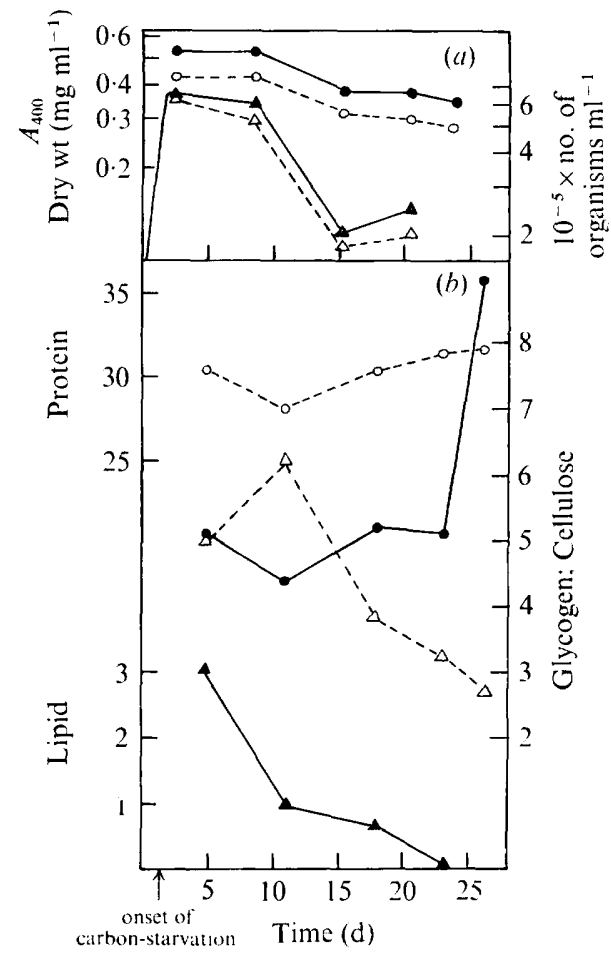

Fig. 1. Changes in dry weight and chemical composition of a carbon-starved suspension of $P$. zopfii. (a) (O) Dry weight, (O) $A_{400}$ of the suspension, ( $\Delta$ ) total number of organisms, $(\triangle)$ number of viable organisms. (b) (O) Total cellular protein, $(\bigcirc)$ cellulose, $(\triangle)$ glycogen-like material, $(\Delta)$ readily extractable lipid, all expressed as a percentage of the dry weight.

organisms $\mathrm{ml}^{-1}$ declined by $62 \%$ and $68 \%$ respectively over $21 \mathrm{~d}$ (Fig. 1 ) ; at the end of this period over $80 \%$ of the organisms remaining were viable. Expressed as a percentage of the dry weight of the organisms, total protein showed no marked changes over the first $18 \mathrm{~d}$ always accounting for about $20 \%$, but after $26 \mathrm{~d}$ rose to $36 \%$ (Fig. $1 \mathrm{~b}$ ). Readily extractable lipid initially comprised more than $3 \%$ of the dry weight, but fell to an undetectable level after $23 \mathrm{~d}$ (Fig. $1 \mathrm{~b}$ ). Cellulose remained at between 7 and $8 \%$ throughout, whereas glycogenlike material decreased by about $50 \%$ over $18 \mathrm{~d}$ (Fig. $1 \mathrm{~b}$ ).

\section{Changes in respiration rates and enzyme activities}

A steady decline in oxygen uptake rates with added acetate as respiratory substrate was observed over $23 \mathrm{~d}$ starvation (Fig. $2 a$ ); typically the rate decreased to $10 \%$ of that observed in an early-stationary phase culture. The endogenous respiration rate also decreased, by about $50 \%$ over $8 \mathrm{~d}$ and then more slowly. In other longer experiments no endogenous respiration was measurable [limit of detection about $1 \mathrm{nmol} \mathrm{min}{ }^{-1}$ (mg dry wt organisms) ${ }^{-1}$ ] after $110 \mathrm{~d}$ starvation, neither were these suspensions able to oxidize added acetate; nevertheless a high proportion $(80 \%)$ of organisms in these suspensions remained viable. The full ability to oxidize acetate was recovered within $2 \mathrm{~d}$ from the time of addition of the respiratory substrate to a suspension of organisms starved for $20 \mathrm{~d}$. Whereas the oxygen uptake of exponentially growing suspensions was cyanide-sensitive $(61,62$ and $12 \%$ inhibition of glucose-supported, acetate-supported and endogenous respiration, respectively, by $10 \mu \mathrm{M}-\mathrm{KCN} ; 45 \%$ inhibition of endogenous respiration by $0.1 \mathrm{~mm}-\mathrm{KCN}$ ), antimycin $\mathrm{A}$ ( $2 \mu \mathrm{g}$ per $10^{5}$ organisms) gave $67 \%$ stimulation of acetate-supported respiration of organisms which had been starved for $15 \mathrm{~d}$. This antimycin A-stimulated respiration was inhibited by subsequent addition of either $1 \mathrm{~mm}-\alpha, \alpha^{\prime}$-bipyridyl or $1 \mathrm{~mm}$-thiocyanate. 


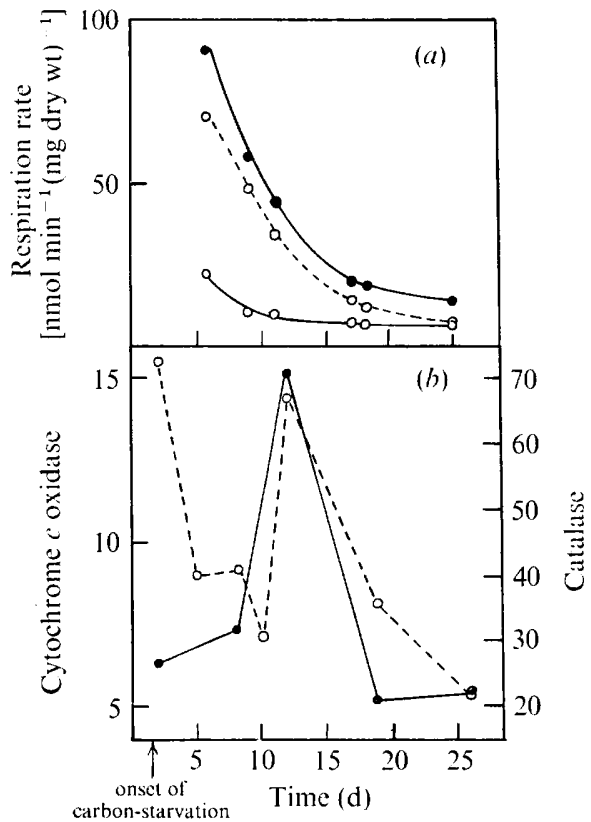

Fig. 2

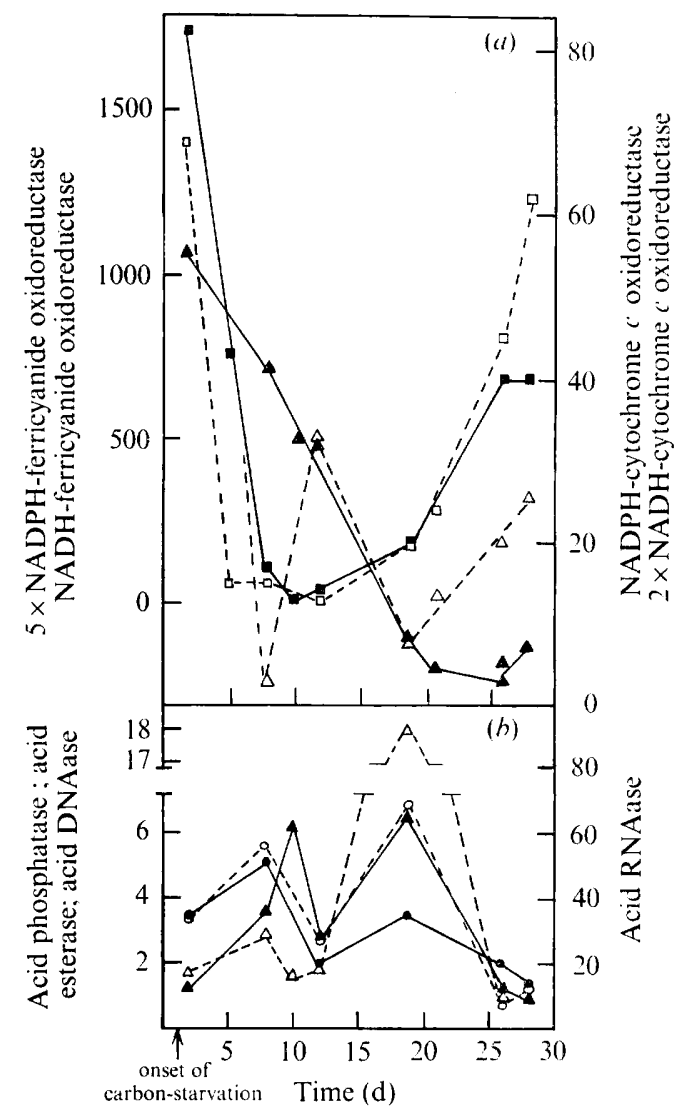

Fig. 3

Fig. 2. Changes in respiration rate, cytochrome $c$ oxidase activity and catalase activity during carbon-starvation of $P$. zopfii. (a) (O) Respiration rate in the presence of $10 \mathrm{~mm}$-sodium acetate, $(\mathrm{O}-\mathrm{O})$ endogenous respiration rate, $\left(\mathrm{O}_{--} \mathrm{O}\right)$ oxygen uptake rate in the presence of acetate after subtraction of the endogenous rate. (b) $(O)$ Cytochrome $c$ oxidase activity, catalase activity, both expressed as specific activities [ $\mathrm{nmol} \mathrm{min}^{-1}(\mathrm{mg} \text { protein })^{-1}$ ].

Fig. 3. Changes in enzyme activities during carbon-starvation of $\boldsymbol{P}$. zopfii. (a) (A) NADPH-cytochrome $c$ oxidoreductase, $(\triangle)$ NADH-cytochrome $c$ oxidoreductase, ( $\square$ ) NADPH-ferricyanide oxidoreductase, $(\square)$ NADH-ferricyanide oxidoreductase. $(b)(\triangle)$ Acid deoxyribonuclease, $(\Delta)$ acid ribonuclease, $(\bullet)$ acid phosphatase, $(\bigcirc)$ acid esterase. Enzyme activities are expressed as specific activities [nmol $\mathrm{min}^{-1}(\mathrm{mg} \text { protein })^{-1}$ ].

Cytochrome $c$ oxidase activity declined sharply to less than one-half of its initial value over the first $9 \mathrm{~d}$ starvation; it then rose sharply to a maximum after $11 \mathrm{~d}$ followed by a second phase of decline to one-third of the value found in the early-stationary phase of growth (Fig. 2b). This profile is quite different from that for the overall respiration rate (Fig. 2a). Catalase activity also increased to a maximum after $11 \mathrm{~d}$ starvation (Fig. $2 b$ ) as did NADH-cytochrome $c$ oxidoreductase activity (Fig. 3a). NADPH-cytochrome $c$ oxidoreductase activity fell continuously until the 25th day of starvation (Fig. $3 a$ ). Both NADH- and NADPH-ferricyanide oxidoreductases initially showed high activities, these declined until the 11 th day and then increased over the following $15 \mathrm{~d}$ (Fig. $3 a$ ). Three of the four acid hydrolases studied showed very similar sequences of changes in activity (Fig. $3 b$ ); they increased to maxima at about the 7th day of starvation then declined until the 11th day before rising to a second maximum on the 17th day. Acid ribonuclease activity showed a 


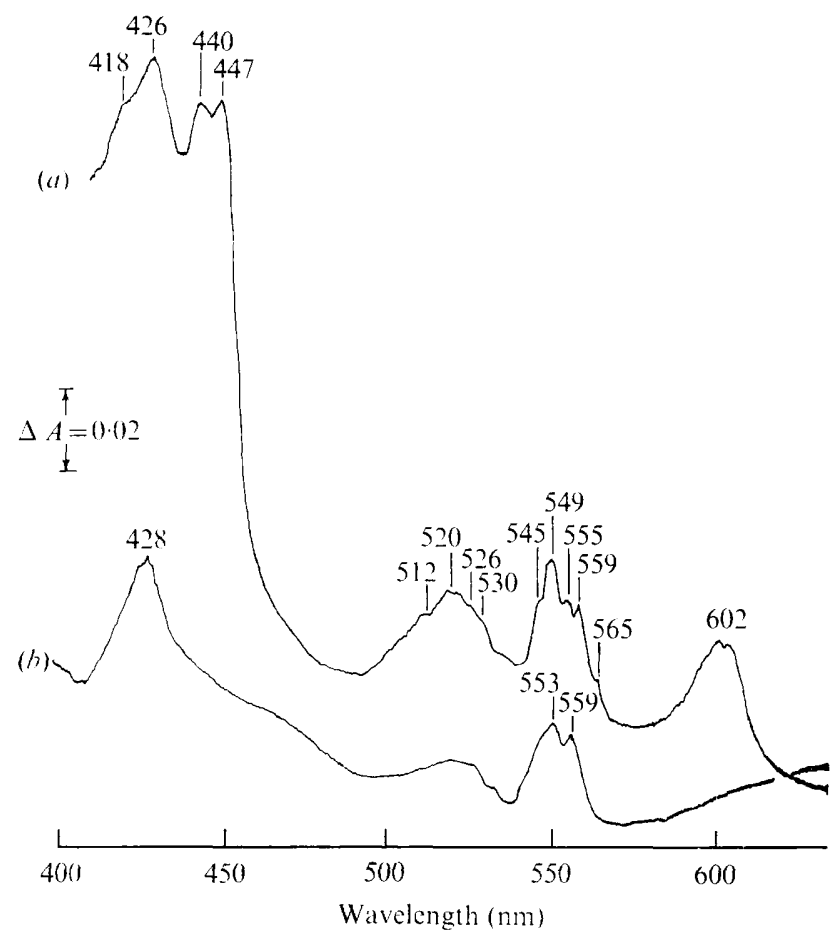

Fig. 4. Difference spectra of whole cells of $P$. zopfii at $77 \mathrm{~K}$. Cells were harvested $(a)$ in the earlystationary phase of growth, and $(b)$ after $24 \mathrm{~d}$ carbon-starvation. They were resuspended in $5 \%$ (v/v) glycerol to final populations of $(a) 5 \cdot 2 \times 10^{8}$ and $(b) 4 \cdot 2 \times 10^{8}$ organisms ml-1. Reduction was with excess sodium dithionite, oxidation with $\mathrm{H}_{2} \mathrm{O}_{2}$. The path length was $2 \mathrm{~mm}$, the scan speed $0.5 \mathrm{~nm} \mathrm{~s} \mathrm{~s}^{-1}$ and the spectral band width $1 \mathrm{~nm}$.

similar timing for the second maximum, but the first maximum occurred on the 9 th day of starvation.

Total protein [expressed as $\mathrm{mg}(\mathrm{ml} \text { culture })^{-1}$ ] did not show any significant decline over $25 \mathrm{~d}$ starvation; the rise in protein content (expressed as a percentage of dry weight, Fig. 1) between days 23 and 26 resulted from loss of other cellular constituents. Therefore similar enzyme profiles to those shown in Figs. 2 and 3 are obtained if the results are presented as enzyme units ( $\mathrm{ml}$ culture $)^{-1}$ instead of specific activities.

\section{Changes in cytochromes}

Figure 4(a) shows a typical low temperature difference spectrum (dithionite-reduced minus $\mathrm{H}_{2} \mathrm{O}_{2}$-oxidized) for organisms from the early-stationary phase of growth. Cytochrome $a+a_{3}$ has a broad $\alpha$-band at around $602 \mathrm{~nm}$ and Soret maxima at 440 and $447 \mathrm{~nm}$. Cytochrome(s) $c$ shows two maxima, at 545 and $549 \mathrm{~nm}$, and three distinct maxima due to the presence of cytochromes $b$ are clearly defined at 555,559 and $565 \mathrm{~nm}$. These characteristics were also observed in spectra of organisms starved for 8 and $16 \mathrm{~d}$. After $24 \mathrm{~d}$ starvation the difference spectrum was altered profoundly (Fig. $4 b$ ); maxima at 428 and $559 \mathrm{~nm}$ are attributable to protohaem or a closely related compound, whilst that at $553 \mathrm{~nm}$ represents haem $c$. No haem $a$ derivative was detected.

\section{Changes in adenine nucleotide pools}

Figure 5(a) shows the decline in endogenous respiration rate and numbers of viable organisms in a carbon-starved culture. Both ATP and ADP pools were rapidly depleted during the first $7 \mathrm{~d}$, to about $1 \%$ and $5 \%$ respectively of their values in the early-stationary 


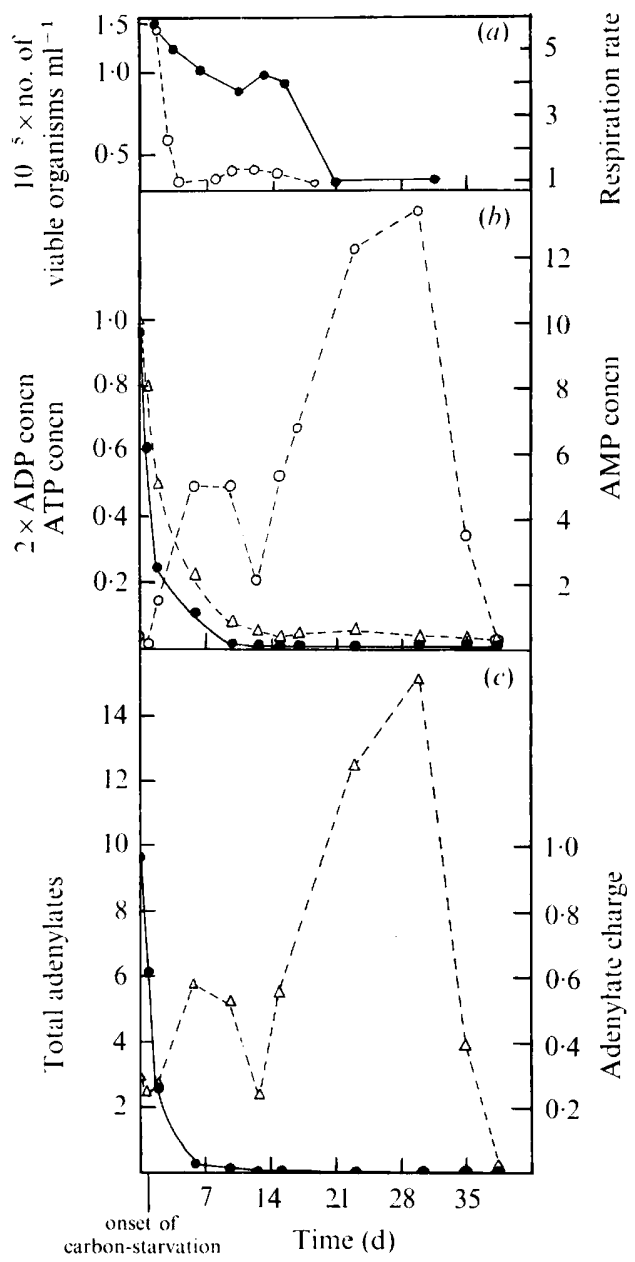

Fig. 5. Changes in adenine nucleotide pools, total adenylates and adenylate charge during carbonstarvation of $P$. zopfii. (a) (O) Endogenous respiration rate $\left[\mathrm{nmol} \mathrm{min}^{-1}(\mathrm{ml} \text { culture })^{-1}\right],(\Theta)$ number of viable organisms. (b) Concentrations of (๑) ATP, ( $\triangle)$ ADP, ( $\bigcirc)$ AMP. (c) (๑) Adenylate charge, $(\triangle)$ total adenylate concentration. All adenylate concentrations are expressed as nmol (ml culture $)^{-1}$.

phase of growth. A concomitant increase in AMP levels occurred (Fig. 5b); a second larger elevation of the AMP content of the culture gave a maximum at around $28 \mathrm{~d}$ followed by a decline to an undetectably low level after $36 \mathrm{~d}$. These massive changes in the AMP pool size are reflected in the pattern of total adenine nucleotides (Fig. $5 c$ ). The adenylate charge decreased from 0.95 in cultures at the onset of the stationary phase to 0.015 after $5 \mathrm{~d}$ starvation and afterwards remained at less than 0.01 for the duration of the experiment (Fig. $5 c$ ). After $32 \mathrm{~d}$ more than $80 \%$ of the AMP detected was present in the medium; when allowance was made for this in the calculation of adenylate charge the value was still less than $0 \cdot 01$.

Fig. 6. Sections of $P$. zopfii from (a) an exponentially growing culture and (b) a culture after $43 \mathrm{~d}$ carbon-starvation. W, Wall; CM, cytoplasmic membrane; M, mitochondrial profiles; OM, outer mitochondrial membrane; IM, cristae membranes; $\mathrm{N}$, nucleus; $\mathrm{NM}$, nuclear membrane; $\mathrm{V}$, vacuole; and IMI, intramitochondrial inclusion. Bar markers represent $1 \mu \mathrm{m}$. 

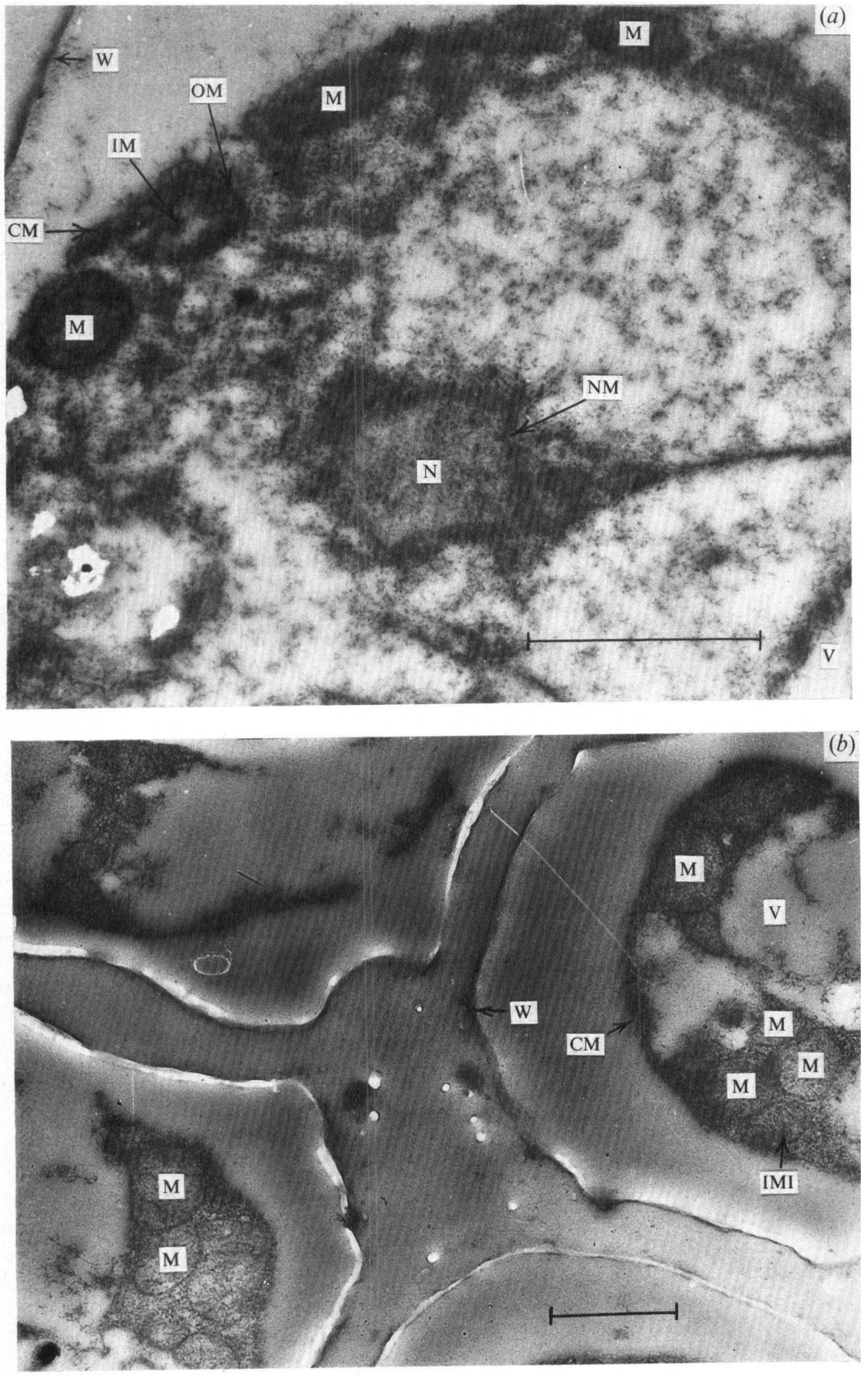


\section{Changes in subcellular organization}

Organisms from the exponential phase of growth were typically ovoid and presented regular oval outlines in thin sections (Fig. 6a). The most obvious features were the thick $(100 \mathrm{~nm})$ multilayered cell wall, mitochondria with highly organized cristae and the nucleus bounded by the nuclear membrane. The gap between the wall and the plasmalemma was also evident in phase contrast micrographs and is thus not an artefact of fixation for electron microscopy. After $43 \mathrm{~d}$ starvation, this gap appeared to have become larger due to shrinkage of the cytoplasmic mass from the wall (Fig. $6 b$ ). The walls were irregular in outline and had lost their innermost layer. Mitochondrial profiles were still discernible, but their cristae were rudimentary and intramitochondrial inclusions were seen.

\section{DISCUSSION}

The growth-limiting nutrient in the defined medium used in this study is acetate (Lloyd $\&$ Callely, 1965), and prolonged aeration of stationary phase cultures provides an ageing population of vegetative organisms. The succession of events in these cultures is as follows: (1) A rapid decline in the ATP and ADP content of organisms is accompanied by a rise in the AMP pool size so that the value for adenylate charge of 0.95 determined for a lateexponential phase population falls to 0.03 after $4 \mathrm{~d}$ carbon-starvation. (2) A phase of decline (over about $10 \mathrm{~d}$ ) in endogenous respiration rates and in the ability to respire added acetate is accompanied by elevated levels of acid hydrolases ( $p$-nitrophenyl phosphatase, arylesterase, deoxyribonuclease and ribonuclease) and loss of easily extracted lipids. (3) The next phase (between days 8 and 15) involves a decline of about $70 \%$ in total and viable cell numbers, a marked loss of reserve polyglucose, catalase and cytochrome $c$ oxidase activities, the onset of a second phase of increased acid hydrolase activities and a vast increase in AMP, possibly as a consequence of extensive degradation of RNA. (4) The last phase (after day 15) is characterized by low respiration rates and adenylate charge, low activities of catalase and cytochrome $c$ oxidase, increasing activities of NADH- and NADPH-ferricyanide oxidoreductases and NADH-, but not NADPH-cytochrome $c$ oxidoreductase, declining activities of acid hydrolases and falling AMP levels. Pathways of electron transport alternative to the main phosphorylating respiratory chain (Lloyd, 1974a, b) are partly responsible for respiration of these organisms as evidenced by the stimulatory effect of antimycin $\mathrm{A}$. The loss of cellular constituents by this stage has led to a situation where the cellulose component of the cell wall accounts for twice the proportion of the dry weight compared with that found in early-stationary phase organisms. The reduced minus oxidized difference spectrum of organisms at this stage indicates that the normal cytochrome complement has been lost, no detectable haem $a$ is present and the $b$ and $c$ components have apparently become modified to give spectra identical to the ferrohaemochromes, protohaem and haem $c$; recognizable mitochondrial profiles can still be distinguished in thin sections although these organelles have lost most of their internal organization.

A decreased value of adenylate charge below about 0.5 does not lead to cell death in eukaryotes, although this dire consequence has been observed in bacteria (Chapman et al., 1971). We have previously observed transient values of 0.47 in synchronously dividing cultures of Crithidia fasciculata (Edwards et al., 1975) and values of less than 0.1 in earlyexponential phase cultures of Acanthamoeba castellanii (Edwards \& Lloyd, 1977). However the concept of adenylate charge as an expression of the balance between energy-yielding and energy-utilizing metabolic reactions is evidently more complex in a highly-compartmented eukaryotic organism.

The long-term survival of $P$. zopfii under conditions of carbon deprivation provides a convenient system for further studies of (i) metabolic changes and control mechanisms, (ii) changes in the structure and function of energy-yielding organelles, and (iii) the roles of 
general and specific degradative systems in the maintenance of viability. Furthermore, these alterations are rapidly reversible in the viable portion of the population. An outstanding problem is the determination of the extent of cryptic growth (Ryan, 1959) in the ageing cultures.

We thank Mrs S. Palmer for expert technical assistance.

\section{REFERENCES}

Atkinson, D. E. \& Walton, G. M. (1967). Adenosine triphosphate conservation in metabolic regulation. Journal of Biological Chemistry 193, 265-275.

Ball, W. J., Jr \& Atkinson, D. E. (1975). Adenylate energy charge in Saccharomyces cerevisiae during starvation. Journal of Bacteriology 121, 975-982.

Bertini, F., Brandes, D. \& Buetow, D. E. (1965). Increased acid hydrolase activity during carbon starvation in Euglena gracilis. Biochimica et biophysica acta 107, 171-173.

Blum, J. J. \& Buetow, D. E. (1963). Biochemical changes during acetate deprivation and repletion in Euglena. Experimental Cell Research 29, 407-421.

Brandes, D., Buetow, D. E., Bertini, F. \& Malkoff, D. E. (1964). Roles of lysosomes in cellular lytic processes. I. Effect of carbon starvation in Euglena gracilis. Experimental and Molecular Pathology (supplement) 3, 583-609.

Callely, A. G. \& Lloyd, D. (1964). The metabolism of acetate in the colourless alga, Prototheca zopfii. Biochemical Journal 90, 483-489.

Cartledge, T. G. \& Lloyd, D. (1972). Subcellular fractionation by differential and zonal centrifugation of aerobically grown glucose derepressed Saccharomyces cerevisiae. Biochemical Journal 126, 381-393.

Chapman, A. G., Fall, L. \& Atrinson, D. E. (1971). Adenosine triphosphate and synchronous mitosis in Physarum polycephalum. Journal of Bacteriology 96, 330-337.

Chung, C. W. \& Nickerson, W. J. (1954). Polysaccharide synthesis in growing yeasts. Journal of Biological Chemistry 208, 395-407.

Edwards, C., Statham, M. \& Lloyd, D. (1975). The preparation of large-scale synchronous cultures of the trypanosomatid, Crithidia fasciculata, by cell-size selection: changes in respiration and adenylate charge through the cell cycle. Journal of General Microbiology 88, 141-152.

Edwards, S. W. \& Lloyd, D. (1977). Changes in oxygen uptake rates, enzyme activities, cytochrome amounts and adenine nucleotide pool levels during growth of Acanthamoeba castellanii in batch culture. Journal of General Microbiology 102, 135-144.

Edwards, S. W., Chagla, A. H., Griffiths, A. J. \& LLOYD, D. (1977). The cytochromes of Acanthamoeba castellanii. Biochemical Journal 168, 113121.

ElliotT, A. M. \& BAK, I. J. (1964). The fate of mitochondria during ageing in Tetrahymena pyriformis. Journal of Cell Biology 20, 113-129.
Huggins, C. \& Lapides, J. (1947). Chromogenic substrates. IV. Acyl esters of $p$-nitrophenol as substrates for the colorimetric determination of esterase. Journal of Biological Chemistry 170, 467-482.

Hughes, D. E. (1951). A press for disrupting bacteria and other micro-organisms. British Journal of Experimental Pathology 32, 97-100.

John, P. C. L., Thurston, C. F. \& Syrett, P. J. (1970). Disappearance of isocitrate lyase from cells of Chlorella pyrenoidosa. Biochemical Journal 119, 913-919.

Katsunuma, T., Schott, E., Elsasser, S. \& Holzer, H. (1972). Purification and properties of tryptophan-synthetase-inactivating enzymes from yeast. European Journal of Biochemistry 27, 520-526.

Levy, M. R. \& ElliotT, A. H. (1968). Biochemical and ultrastructural changes in Tetrahymena pyriformis during starvation. Journal of Protozoology 15, 208-222.

Levy, M. R., Sisskin, E. E. \& McConkey, C. L. (1976). A protease that increases during a period of enzymic and metabolic adjustment in Tetrahymena. Archives of Biochemistry and Biophysics 172, 634-647.

LLOYD, D. (1974a) Mitochondria of Microorganisms. London, New York: Academic Press.

Lloyd, D. (1974b). Dark respiration. In Algal Physiology and Biochemistry, pp. 505-529. Edited by W. D. P. Stewart. Oxford: Blackwells Scientific Publications.

Lloyd, D. \& Brookman, J. S. G. (1967). An oxygen electrode reaction vessel. Biotechnology and Bioengineering 9, 271-272.

Lloyd, D. \& CAllely, A. G. (1965). The assimilation of acetate and propionate by Prototheca zopfii. Biochemical Journal 97, 176-179.

Lowry, O. H., Rosebrough, N. J., Farr, A. L. \& Randall, R. J. (1951). Protein measurement with the Folin phenol reagent. Journal of Biological Chemistry 193, 265-275.

Luzikov, N., Makhlis, T. A. \& Galkin, A. V. (1976). A probable role of cell proteinases in the biogenesis of mitochondria in yeast. FEBS Letters 69, $108-110$.

Miura, T. \& Yanagita, T. (1972). Cellular senescence in yeast caused by carbon-source starvation. I. Changes in activities of respiratory system and lipid peroxidation activity. Journal of Biochemistry 72, 141-148.

Morris, I. \& SyretT, P. J. (1965). The effect of nitrogen starvation on the activity of nitrate reductase and other enzymes in Chlorella. Journal of General Microbiology 38, 21-28. 
Müller, M., Baudhuin, P. \& de Duve, C. (1966). Lysosomes on Tetrahymena pyriformis. I. Some properties and lysosomal location of acid hydrolases. Journal of Cellular Physiology 68, 165-175.

RYAN, F. J. (1959). Bacterial mutation in a stationary phase and the question of cell turnover. Journal of General Microbiology 21, 530-549.
StickLAND, L. H. (1951). The determination of small quantities of bacteria by means of the biuret reaction. Journal of General Microbiology 5, 698-703.

Trinci, A. P. J. \& Thurston, C. F. (1976). Transition to the non-growing state in eukaryotic microorganisms. Symposia of the Society of General Microbiology 26, 55-79. 